\title{
Transcription factor p53 can regulate proliferation, apoptosis and secretory activity of luteinizing porcine ovarian granulosa cell cultured with and without ghrelin and FSH
}

\author{
A V Sirotkin ${ }^{1,2}$, A Benčo ${ }^{2}$, A Tandlmajerova ${ }^{2}$, D Vašíček ${ }^{1}$, J Kotwica ${ }^{3}$, K Darlak $^{4}$ and F Valenzuela $^{4}$ \\ ${ }^{1}$ Department of Genetics and Reproduction, Research Institute of Animal Production, Slovak Centre of Agricultural \\ Studies, Hlohovská 2, 94992 Nitra, Slovakia, ${ }^{2}$ Konstantin the Philosopher University, 94974 Nitra, Slovakia, ${ }^{3}$ Institute \\ of Animal Reproduction and Food Research, 10-718 Olsztyn-Kortowo, Poland and ${ }^{4}$ Peptides International Inc., \\ Louisville, Kentucky 40299, USA \\ Correspondence should be addressed to A V Sirotkin; Email: sirotkin@scpv.sk
}

\begin{abstract}
The aim of our in vitro experiments was to examine the role of transcription factor p53 in controlling the basic functions of ovarian cells and their response to hormonal treatments. Porcine ovarian granulosa cells, transfected and non-transfected with a gene construct encoding p53, were cultured with ghrelin and FSH (all at concentrations of $0,1,10$, or $100 \mathrm{ng} / \mathrm{ml}$ ). Accumulation of p53, of apoptosisrelated (MAP3K5) and proliferation-related (cyclin B1) substances was evaluated by immunocytochemistry. The secretion of progesterone $\left(\mathrm{P}_{4}\right)$, oxytocin $(\mathrm{OT})$, prostaglandin $\mathrm{F}(\mathrm{PGF})$, and $\mathrm{E}(\mathrm{PGE})$ was measured by RIA. Transfection with the p53 gene construct promoted accumulation of this transcription factor within cells. It also stimulated the expression of a marker of apoptosis (MAP3K5). Over-expression of p53 resulted in reduced accumulation of a marker of proliferation (cyclin B1), $\mathrm{P}_{4}$, and PGF secretion and increased OT and PGE secretion. Ghrelin, when added alone, did not affect $\mathrm{p} 53$ or $\mathrm{P}_{4}$, but reduced MAP3K5 and increased PGF and PGE secretion. Over-expression of p53 reversed the effect of ghrelin on OT, caused it to be inhibitory to $\mathrm{P}_{4}$ secretion, but did not modify its action on MAP3K5, PGF, or PGE. FSH promoted the accumulation of p53, MAP3K5, and cyclin B1; these effects were unaffected by p53 transfection. These multiple effects of the p53 gene construct on luteinizing granulosa cells, cultured with and without hormones 1) demonstrate the effects of ghrelin and FSH on porcine ovarian cell apoptosis and secretory activity, 2) confirm the involvement of p53 in promoting apoptosis and inhibiting $P_{4}$ secretion in these cells, 3) provide the first evidence that p53 suppress proliferation of ovarian cells, 4) provide the first evidence that p53 is involved in the control of ovarian peptide hormone (OT) and prostaglandin (PGF and PGE) secretion, and 5) suggest that p53 can modulate, but probably not mediate, the effects of ghrelin and FSH on the ovary.

Reproduction (2008) $136611-618$
\end{abstract}

\section{Introduction}

Transcription factor p53 has been shown to be an important inducer of apoptosis and blocker of proliferation in different cell types. Under stress conditions, it induces of $\mathrm{G} 1 / \mathrm{S}$ cell-cycle arrest (through transcription factors $\mathrm{p} 21$ and c-MYC) and G2/M cycle arrests (through cyclin B and CDC2 kinase; Brown et al. 2007). It can activate mitochondrial caspases, which cleave MAP kinases (activators of CDC2 kinases and cell cycle at G2/M phase; Marchetti et al. 2004) and induce apoptosis-related events (Braithwaite et al. 2006, Chowdhury et al. 2006). When concerned with the role of p53 in controlling secretory activity, it is able to suppress growth factor secretion (VEGF, Hassan et al. 2006) and insulin-like growth factor binding proteins (Grimberg et al. 2006), and to promote vasopressin and catecholamine secretion (Chernigovskaya et al. 2005).
The presence of p53 was demonstrated in mammalian (Chaffin et al. 2003, Herr et al. 2004, Hussein et al. 2006, Mészárosová et al. 2007) and avian (Sirotkin et al. 2006, Sirotkin \& Grossmann 2007b) ovarian cells. In porcine (Hussein et al. 2006) and avian (Sirotkin \& Grossmann 2007b) ovarian cells, its expression was associated with apoptosis and atresia of ovarian follicles indicating involvement of p53 in the control of these processes. Indeed, in rat and macaque ovarian granulosa cells, it promoted apoptosis and basal progesterone $\left(\mathrm{P}_{4}\right)$ and pregnenolone secretion (Amsterdam et al. 2003, Cherian-Shaw et al. 2004), but not proliferation (Cherian-Shaw et al. 2004). Therefore, involvement of p53 might be proposed in the control of ovarian follicle luteinization, atresia, and remodeling. Nevertheless, evidence for the role of p53 in controlling ovarian function is limited to its ability to promote granulosa cell 
apoptosis and steroidogenesis. Its involvement in regulating ovarian cell proliferation and secretion of non-steroidal hormones (peptides, prostaglandins) has not yet been studied.

There is evidence that p53 not only regulates basal ovarian function directly but also mediates the effects of hormones. p53 accumulation in ovarian granulosa cells can be induced by glucocorticoids (women; Amsterdam et al. 2003), gonadotropins (women; Chaffin et al. 2003, Herr et al. 2004), leptin (pig; Dineva et al. 2007), ghrelin (chicken; Sirotkin et al. 2006), and obestatin (pig; Mészárosová et al. 2007), but inhibited by leptin (chicken; Sirotkin \& Grossmann 2007b). Moreover, blockade of p53 prevented hCG-induced progestagen, but not estradiol, secretion by human granulosa cells (Cherian-Shaw et al. 2004). It remains unknown whether gonadotropin and ghrelin affect ovarian function through an increase in p53 accumulation. Such a mediating role for p53 would be demonstrated by concomitant hormonal stimulation of p53 and the promotion of hormonal action.

The aim of the present study was to examine the role of p53 in controlling apoptosis and secretory activity of luteinizing porcine ovarian cells cultured with and without peptide hormones. In our experiments, we examined the effects of the well-known (Wathes 1989, Sirotkin et al. 1998, 2001, Schams et al. 1999, Jiang et al. 2003, Maillet et al. 2005) gonadotropin follicle-stimulating hormone (FSH) and of the newly discovered hormone ghrelin, whose involvement in the control of avian (Sirotkin et al. 2006, Sirotkin \& Grossmann 2007a, $2007 \mathrm{~b}$ ) and mammalian (Sirotkin et al. 2007, 2008, Tena-Sempere 2008) reproduction has been recently demonstrated. We have also investigated whether p53 may mediate the action of these hormones in the ovary. Using granulosa cells, we have studied a) the influence of transfection with the p53 gene construct encoding p53 on cell apoptosis (accumulation of MAP3K5), proliferation (accumulation of cyclin B1), and secretory activity (secretion of $\mathrm{P}_{4}$, oxytocin (OT), prostaglandin $\mathrm{F}$ (PGF), and $E(P G E)), b)$ the effect of the hormones ghrelin and FSH on p53 accumulation and on selected parameters listed above, and c) the ability of the p53 gene construct to mimic or modify the effects of hormones. Two independent series of experiments were carried out. The main purpose of these experiments was to understand the role of p53, but not of hormones, in control of basic ovarian functions. Therefore, to improve the reliability of the data concerning p53 effects, we have analyzed the samples obtained in different experiments to measure the effect of p53 (but not of hormones) on all possible parameters. The following series of experiments was performed: 1) investigation of the effect of ghrelin and p53 transfection on the expression of p53, MAP3K5, and the secretion of $\mathrm{P}_{4}, \mathrm{OT}, \mathrm{PGF}$, and PGE and 2) the investigation of the effect of $\mathrm{FSH}$ and p53 transfection on the expression of p53, MAP3K5, and cyclin B1.

\section{Results}

Ovarian cells after culture contained markers of apoptosis and proliferation, p53, and secreted the assayed hormones. In addition, after transfection, 40-55\% of granulosa cells produced enhanced green fluorescent protein (EGFP), indicative of successful cell transgenesis (Fig. 1).

\section{Series 1: influence of ghrelin on expression of p53 and MAP3K5 and secretion of hormones by cultured porcine granulosa cells transfected or non-transfected with gene construct encoding p53}

Immunocytochemical analysis confirmed the presence of p53 in cultured cells (Fig. 2a) and demonstrated the presence of MAP3K5 (Fig. 2b). p53 was located mainly in the nuclei, while MAP3K5 was found mainly in cytoplasm. RIA confirmed the secretion of $\mathrm{P}_{4}, \mathrm{OT}, \mathrm{PGF}$, and PGE by these cells (Fig. 3).

Over-expression of p53 in transfected cells was confirmed by immunocytochemistry. Ghrelin did not affect the proportion of p53-positive control cells but decreased it in transfected cells (at all concentrations added; Fig. 2a).

Over-expression of p53 was associated with an increased proportion of cells containing MAP3K5. Ghrelin reduced this index in both control cells (at concentration $100 \mathrm{ng} / \mathrm{ml}$ ) and transfected cells (at concentrations 10 and $100 \mathrm{ng} / \mathrm{ml}$; Fig. 2b).

Transfection of cells decreased the secretion of $\mathrm{P}_{4}$ secretion. Ghrelin did not affect this index in control cells, but inhibited $\mathrm{P}_{4}$ secretion by transfected cells at concentrations 1 or $10 \mathrm{ng} / \mathrm{ml}$ (Fig. 3a). Transfection induced an increase in OT secretion. Ghrelin (at 10 and

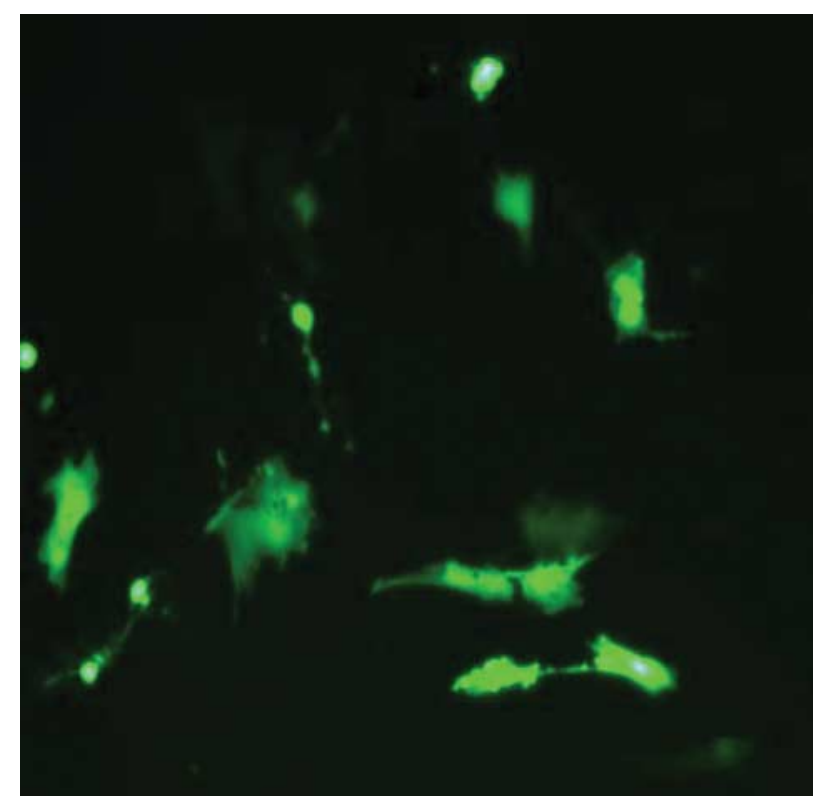

Figure 1 Presence of enhanced green fluorescent protein (EGFP; green fluorescence) as a marker of successful transfection in cultured porcine ovarian granulosa cells. Magnification, $800 \times$. Fluorescence microscopy. 

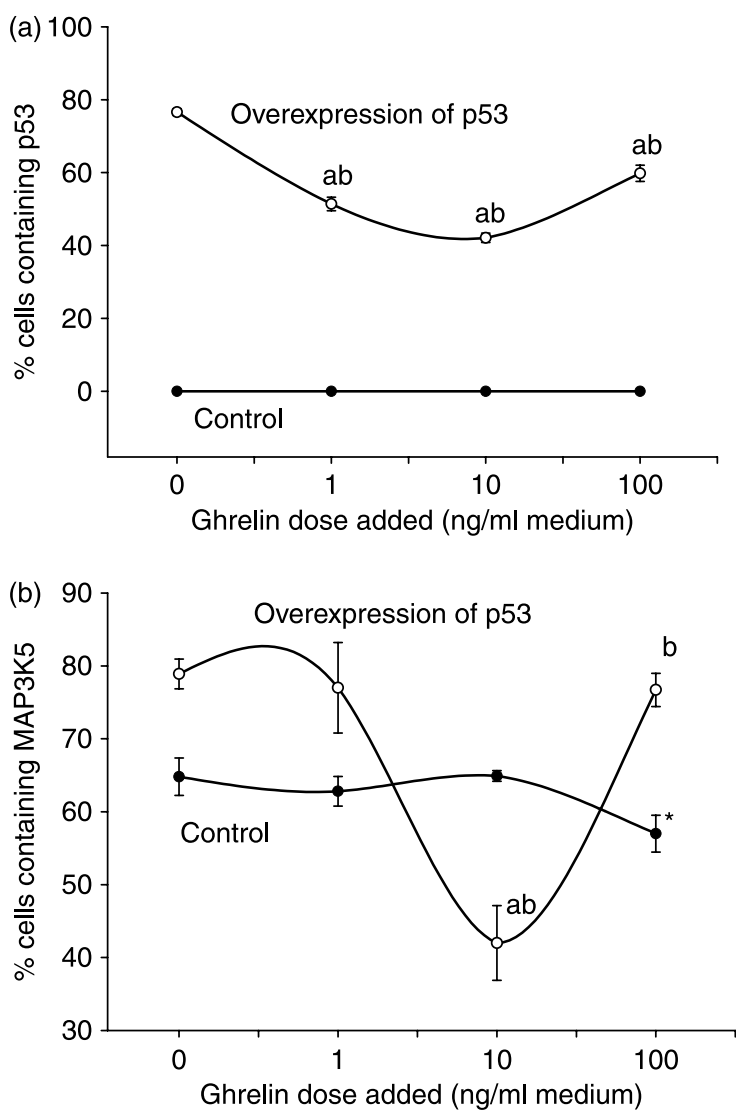

Figure 2 Influence of ghrelin on expression of p53 (a) and MAP3K5 (b) in cultured porcine granulosa cells transfected or non-transfected with gene construct encoding p53. Data from immunocytochemistry; a) significant $(P<0.05)$ difference between hormone-treated $(1,10$ or $100 \mathrm{ng} / \mathrm{ml})$ and control $(0 \mathrm{ng} / \mathrm{ml})$ cells; b) a significant $(P<0.05)$ difference between corresponding groups of transfected and non-transfected cells.

$100 \mathrm{ng} / \mathrm{ml}$ ) significantly increased OT output in control cells, but decreased it (at all concentrations) in transfected cells (Fig. 3b).

Over-expression of p53 induced a substantial decrease in PGF secretion. Ghrelin stimulated PGF secretion by control (all concentrations) and transfected $(10$ and $100 \mathrm{ng} / \mathrm{ml})$ cells, although a significant reduction of PGF secretion by ghrelin treated to transfected cells $(1 \mathrm{ng} / \mathrm{ml})$ in comparison with control was observed (Fig. 3c).

PGE secretion was increased in transfected cells. Ghrelin promoted PGE secretion in both control (10 or $100 \mathrm{ng} / \mathrm{ml}$ ) and transfected (1 or $10 \mathrm{ng} / \mathrm{ml}$ ) cells (Fig. 3d).

\section{Series 2: influence of FSH on expression of p53, MAP3K5, and cyclin B1 in cultured porcine granulosa cells transfected or non-transfected with gene construct encoding $p 53$}

This series of experiments confirmed the presence of p53, MAP3K5, and cyclin B1 in cultured cells (Fig. 4). As in the previous experiments, after transfection there was

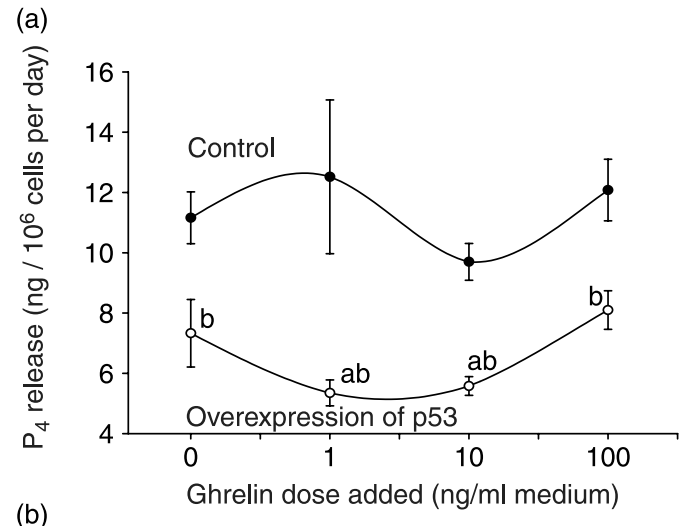

(b)
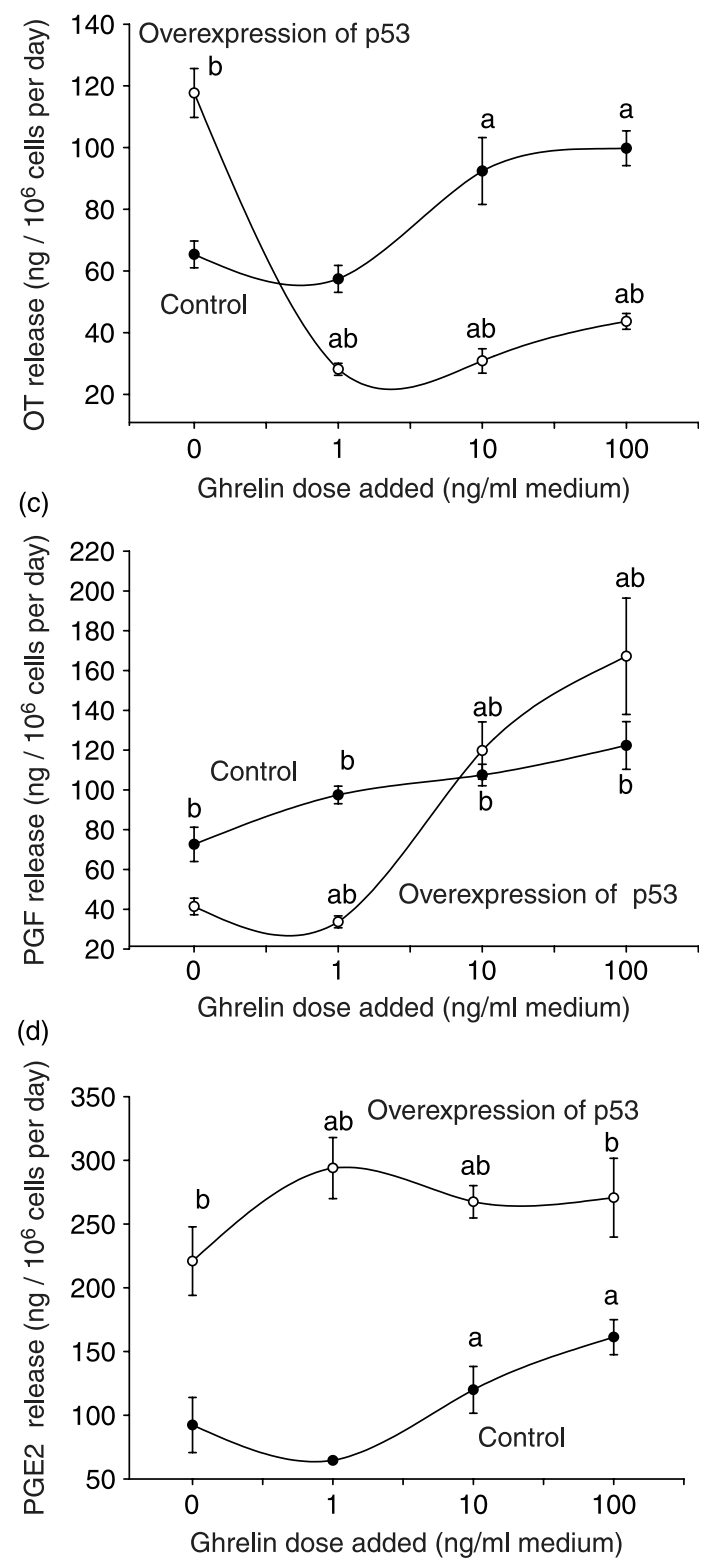

Figure 3 Influence of ghrelin on progesterone (a), oxytocin (b), prostaglandin $\mathrm{F}(\mathrm{c})$, and prostaglandin $\mathrm{E}(\mathrm{d})$ secretion by cultured porcine granulosa cells transfected or non-transfected with gene construct encoding p53. RIA data. Legends as in Fig. 2. 

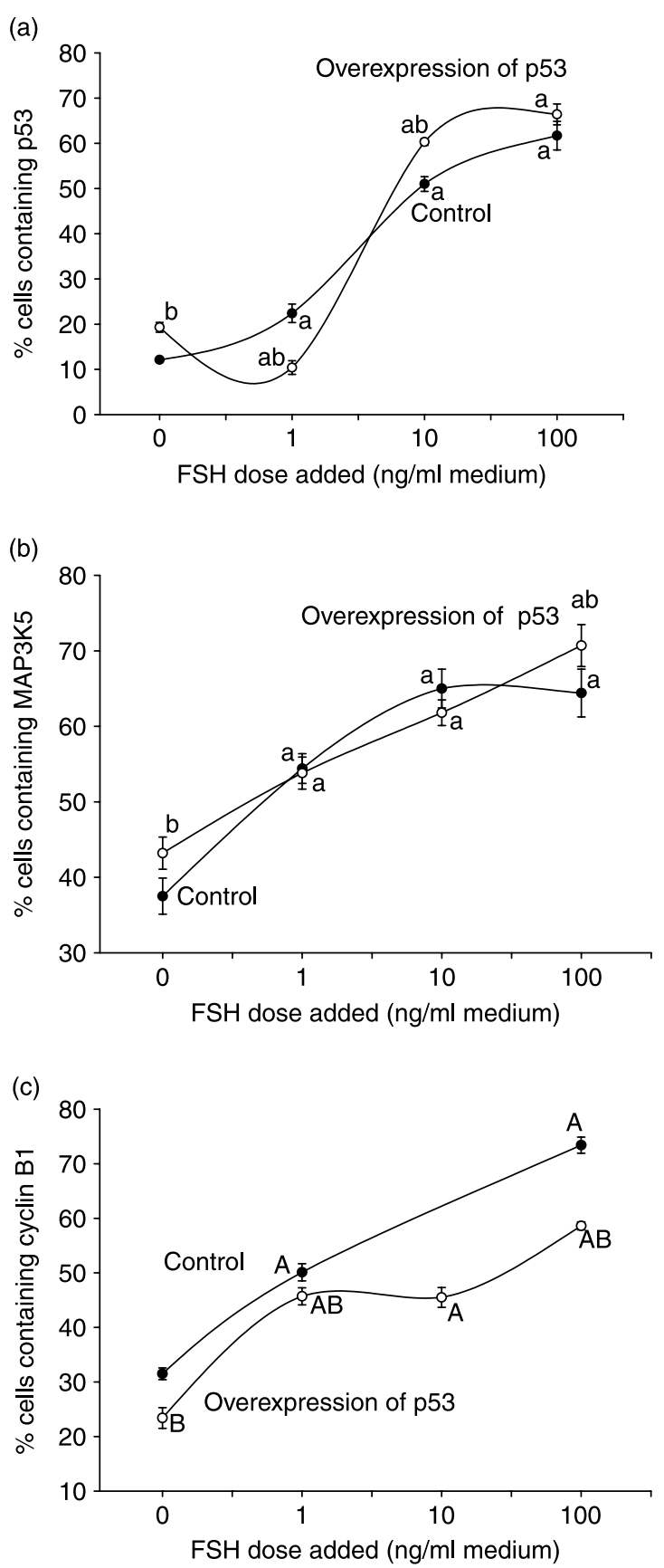

Figure 4 Influence of FSH on expression of p53 (a), MAP3K5 (b), and cyclin B1 (c) in cultured porcine granulosa cells transfected or nontransfected with gene construct encoding p53. Data from immunocytochemistry. Legends as in Fig. 2.

an increase in the percentage of cells containing p53. FSH increased the proportion of these cells in both control (all concentrations) and experimental groups (10 and $100 \mathrm{ng} / \mathrm{ml}$ ), although in transfected cells $\mathrm{FSH}$ addition at dose $1 \mathrm{ng} / \mathrm{ml}$ resulted in some decrease in the proportion of p53-positive cells (Fig. 4a).

As in previous experiments, over-expression of p53 induced an increase in the proportion of cells containing apoptosis-associated MAP3K5. FSH enhanced this parameter in control and transfected cells at all concentrations added (Fig. 4b). Transfection also reduced the occurrence of cyclin B1. FSH increased the expression of this marker in control and transfected cells at all concentrations used (Fig. 4c).

\section{Discussion}

Immunocytochemistry demonstrated a dramatic increase in accumulation of p53 in cultured luteinizing ovarian granulosa cells transfected with the gene construct encoding p53, indicating the over-expression of this transcription factor in these cells. Comparison of transfected and non-transfected cells cultured without hormones suggest that over-expression of p53 is associated with increased apoptosis (expression of apoptosis-related substance MAP3K5). Our data confirm the role of p53 as the promoter of apoptosis, previously shown in nonovarian (Braithwaite et al. 2006, Chowdhury et al. 2006) and ovarian (Amsterdam et al. 2003, Cherian-Shaw et al. 2004, Hussein et al. 2006, Sirotkin \& Grossmann 2007b) cells. These data suggest the involvement of p53 in the promotion of ovarian apoptosis and apoptosis-related atresia and the selection of ovarian follicles, although this hypothesis should be confirmed by direct measurement of apoptosis in atretic follicles.

The inhibitory influence of p53 over-expression on the accumulation of cyclin B1 observed in our experiments is the first demonstration of an anti-proliferative role for this transcription factor in the ovary. Previously, the antiproliferative action of p53 was described only in nonovarian cells (Marchetti et al. 2004, Brown et al. 2007), and it was not observed in macaque ovarian cells (Cherian-Shaw et al. 2004). The ability of p53 to suppress cyclin B1 (marker and promoter of G2 phase of mitosis) suggests that p53 can block the ovarian cell cycle at this checkpoint. These observations suggest the involvement of p53 in the inhibition of ovarian cell proliferation and the resulting growth of ovarian follicles, although this suggestion needs to be confirmed by direct measurement of cell numbers in growing follicles.

The inhibitory effect of p53 on $\mathrm{P}_{4}$ and PGF secretion and its stimulatory influence on OT and PGE output demonstrates that p53 can be a potent regulator of ovarian secretory activity. This is the first evidence for its involvement in ovarian peptide hormone and prostaglandin secretion and it corresponds with a previous report (Amsterdam et al. 2003) on p53 involvement in rat ovarian steroidogenesis, although there it stimulated rather than inhibited the progestagen secretion. The variety of p53 effects on ovarian steroidogenesis observed in different laboratories could be due to the different experimental models used (animal species and the state of ovarian follicle). Nevertheless, the action of p53 on ovarian $\mathrm{P}_{4}$ and PGF suggest its involvement in control of ovarian cell luteinization, where $\mathrm{P}_{4}$ and PGF are important markers and regulators (Wathes 1989, Kotwica \& Skarzynski 1993, 
Findlay 1994, Schams et al. 1999). It is possible that p53 action could be mediated by OT, growth factors, and growth factor-binding proteins, which were shown to control ovarian cell proliferation, apoptosis, and secretory activity (Wathes 1989, Sirotkin et al. 1998, 2001, Schams et al. 1999) and which could be influenced by p53 in both non-ovarian (Grimberg etal. 2006, Hassan et al. 2006) and ovarian (Fig. 3b) cells. Taken together, the observed p53induced promotion of apoptosis, suppression of proliferation, and secretion of hormones - markers and regulators of granulosa cell luteinization - suggest that in physiological conditions this transcription factor can inhibit development of ovarian follicle and/or ovarian cell luteinization and formation of the corpus luteum. This hypothesis requires further experimental confirmation.

The present observations represent the first evidence for involvement of ghrelin in control of porcine ovarian cell functions (proliferation, apoptosis, and hormone release). Inhibitory action of ghrelin on the expression of MAP3K5 suggests possible anti-apoptotic action of ghrelin in porcine ovary. The stimulatory influence of ghrelin on porcine ovarian cell OT, PGF, and PGE, but not $\mathrm{P}_{4}$, release demonstrates its role as a promoter of ovarian secretory activity. It is possible that the ability of ghrelin to suppress apoptotic markers and PGs is due to its action on OT, whose involvement in the control of PGF, PGE, and anti-apoptotic insulin-like growth factor-1 release by porcine ovarian cells has been demonstrated previously (Sirotkin et al. 1998, 2001). They are in line with reports on direct ghrelin action on chicken (Sirotkin et al. 2006, Sirotkin \& Grossmann 2007a) and rabbit (Sirotkin et al. 2008) ovarian cells. The effects of FSH presented here correspond with the ability of $\mathrm{FSH}$ to promote both proliferation, apoptosis, luteinization, and the release of peptide and steroid hormones in ovarian cells reported previously (Wathes 1989, Sirotkin et al. 1998, 2001, Schams et al. 1999, Jiang et al. 2003, Maillet et al. 2005). Their pro-apoptotic and pro-proliferative effects suggest the important role of $\mathrm{FSH}$ in the promotion of ovarian follicular waves, including the promotion of follicular growth, differentiation, and atresia, as well as in ovarian luteogenesis demonstrated previously (Findlay 1994, Jiang et al. 2003). The fine interrelationships between different hormones in control of these ovarian parameters remain for further studies, but differences in the dose-response curves of hormones and pattern of their effects indirectly suggest different physiological roles, as well as the existence of multiple receptors and/or second messenger systems mediating the effects of ghrelin and FSH on the ovary.

It remains unknown whether p53 can mediate the effects of these hormones on ovarian cells. As postulated above, p53 could be considered as a mediator of hormone action if 1) the hormone affects p53 and 2) p53 mimics or modifies the effect of the hormone. Regarding the first requirement, previous studies have demonstrated the stimulatory action of gonadotropin (women; Chaffin et al. 2003, Herr et al. 2004), leptin (pig; Dineva et al. 2007), ghrelin (chicken; Sirotkin et al. 2006), and obestatin (pig; Mészárosová et al. 2007) on p53 accumulation in ovarian cells in different species, although in some cases it was inhibited by leptin (chicken; Sirotkin \& Grossmann 2007b). A stimulatory effect of gonadotropin, but not of ghrelin, was observed in our experiments as well, although the present methods do not definitely show whether the hormone affected the number of cells containing p53 or p53 accumulation in each cell. On the other hand, ghrelin, in contrast to FSH, reduced over-expression of p53 in transfected cells. This could suggest potential direct or feedback inhibitory influence of ghrelin on p53, expressed in conditions of p53 overproduction. Concerning the second requirement, the effects of p53 and a hormone have not previously been studied in the same experiment, although the ability of a p53 blocker to prevent gonadotropin function has been described (CherianShaw et al. 2004). In our experiments, p53 had some similar effects to those of ghrelin (on OT, and PGE, but not on MAP3K5, $\mathrm{P}_{4}$, and PGF) and FSH (on MAP3K5, but not on cyclin B1). Furthermore, p53 was able to promote, suppress, and invert some effects of ghrelin (on MAP3K5, $\mathrm{P}_{4}, \mathrm{OT}$, but not on PGF and PGE). This fact can indirectly indicate that some effects of ghrelin could be mediated by p53. Over-expression of p53 did not substantially modify FSH action on MAP3K5 and cyclin B1). On the other hand, FSH treatment increased both p53 and MAP3K5 in both control and p53-transfected cells. Thus, p53 could be the mediator of $\mathrm{FSH}$ stimulation of MAP3K 5 expression in cells. In contrast, the opposing effects of p53 and FSH on cyclin B1 expression seem to be independent, and p53 expression does not seem to interfere with the ability of FSH to induce cyclin B1 expression.

Evaluation of these results according to the two criteria listed above shows that none of the hormones tested meets all the requirements for describing p53 as mediator in all aspects of ovarian function. Therefore, the present data do not provide decisive evidence for a mediator role of p53 in the actions of ghrelin and FSH. Probably, such evidence could provide studies of the consequences of p53 deficiency in vivo or in vitro. Nevertheless, the ability of p53 to modify ghrelin action observed in our experiments suggest the functional interrelationships between this transcription factor and metabolic hormone in control of ovarian cell apoptosis, proliferation, secretory activity, and related events (follicular growth, differentiation, selection, luteinization, and atresia).

Taken together, these observations are an effect of the p53 gene construct on nine parameters of luteinizing granulosa cell activity, in the presence and absence of hormones to 1) demonstrate the influence of ghrelin and FSH on porcine ovarian cell proliferation, apoptosis, and 
secretory activity, 2) provide the first demonstration that p53 suppresses ovarian cell cycle, 3) confirm the involvement of p53 in promoting apoptosis and in control of $\mathrm{P}_{4}$ secretion by these cells, 4) provide the first evidence that p53 may control ovarian peptide hormone (OT) and prostaglandin (PGF and PGE) secretion, and 5) suggest that p53 is a modulator, but probably not a mediator, of ghrelin and FSH action on the ovary.

\section{Materials and Methods}

\section{Preparation, culture, and processing of ovarian cells}

Ovaries of non-cycling pubertal gilts, about 180 days of age, were obtained after slaughter at a local abattoir. They were washed several times ( $5 \mathrm{~s}$ each) in sterile $0.9 \% \mathrm{NaCl}$ and $95 \%$ alcohol. Granulosa cells were aspirated by syringe and sterile needle from follicles 3-5 mm in diameter, suspended in Dulbecco's modified Eagle's medium (DMEM)/F-12 1:1+2\% fetal calf serum (all from Sigma), and washed twice by centrifugation at $200 \mathrm{~g}$ for $10 \mathrm{~min}$ and resuspended in DMEM/F-12+2\% FCS. Three kinds of plasmids were subcloned from plasmid pcDNA3/pc53-SN3 and used for transfection of granulosa cells: an expression vector for p53 construct containing an insertion for resistance to ampicillin (University of Dundee, Dundee, UK), a 'scramble' control plasmid vector without p53 insertion (University of Dundee), and a marker reporter plasmid pEGFP-N1 for EGFPand resistance to kanamycin (Clontech). The wild-type pc53-SN3 construct containing a $1.8 \mathrm{~kb}$ insert of 13 copies of p53 RE 5'-CCTGCCTGGACTTGCCTGG-3' was as described previously (Baker et al. 1990). These plasmids were multiplied by the following procedures: bacteria Escherichia colis stem $\mathrm{DH} 5 \alpha$ were cultured in $\mathrm{LB}$ medium consisting of $1 \mathrm{I} \mathrm{H}_{2} \mathrm{O}, 10 \mathrm{~g}$ tryptone, $5 \mathrm{~g}$ yeast autolysate, and $10 \mathrm{~g} \mathrm{NaCl} ; \mathrm{pH} 7.0$ with $\mathrm{NaOH} ; 1 \mathrm{ml}$ of $\mathrm{LB}$ medium was inoculated with one colony of $E$. coli stem $\mathrm{DH} 5 \alpha$ and incubated at $37^{\circ} \mathrm{C}, 200 \mathrm{~g} ; 10 \mathrm{ml}$ of LB medium was inoculated with $100 \mu \mathrm{l}$ night bacterial culture and incubated for $3 \mathrm{~h}$ at $37^{\circ} \mathrm{C}, 200 \mathrm{~g}$. The cell suspension was cooled for $10 \mathrm{~min}$ and centrifuged at $200 \mathrm{~g}$ for $10 \mathrm{~min}$ at $4{ }^{\circ} \mathrm{C}$. Cells were resuspended in $10 \mathrm{ml}$ ice-cold $100 \mathrm{mM} \mathrm{CaCl} 2$. The cell suspension was centrifuged at $200 \mathrm{~g}$ for $10 \mathrm{~min}$ at $4{ }^{\circ} \mathrm{C}$. Sedimented cells were resuspended in $2 \mathrm{ml}$ ice-cold $100 \mathrm{mM}$ $\mathrm{CaCl}_{2}$. Aliquots $(200 \mu \mathrm{l})$ of competent cells resuspended in cold
Eppendorf tubes (Greiner bio-one, Longwood, FL, USA) were placed in a refrigerator at $4{ }^{\circ} \mathrm{C}$.

To 10 aliquots $(200 \mu \mathrm{l})$ of competent cells in each tube, $50 \mathrm{ng}$ DNA $(10 \mu \mathrm{l})$ was added to be cloned, mixed, and incubated on ice for $30 \mathrm{~min}$. Tubes were preheated in a water bath at $42{ }^{\circ} \mathrm{C}$ for $90 \mathrm{~s}$ and quickly cooled in ice for $1-2 \mathrm{~min}$. Thereafter, $0.8 \mathrm{ml}$ SOC medium was added to each tube and incubated for $45 \mathrm{~min}$ at $37^{\circ} \mathrm{C}$. A proportionate quantity of bacteria was inoculated in selective LB medium with agar (15 g of agar in 1 I LB medium) in a Petri dish (Gama, a. s. České Budějovice, Czech Republic) and incubated at $37^{\circ} \mathrm{C}$ for $16 \mathrm{~h}$. Five milliliters of $L B$ medium with ampicillin (Gibco BRL) for p53-related plasmids and kanamycin (Gibco) for EGFP-N1 was inoculated with one colony of transformed cells and incubated overnight at $37^{\circ} \mathrm{C}$ and $200 \mathrm{~g}$. The cell suspension was centrifuged at $200 \mathrm{~g}$ at $4{ }^{\circ} \mathrm{C}$ for $10 \mathrm{~min}$. Recombinant plasmids were isolated using a NucleoSpin Plasmid kit (Macherey Nagel, Düren, Germany) according to the manufacturer's instructions.

An experimental group of cells was transfected with a gene construct encoding EGFP and a gene construct for transcription factor p53. A control group of granulosa cells was transfected by a gene construct encoding EGFP and the same, but insertless plasmid vector. Transfection was performed using transfection reagent Roti Fect (Carl Roth, Karlsruhe, Germany) according to the manufacturer's instructions.

After transfection, granulosa cells $\left(1 \times 10^{6}\right.$ cells $\left./ \mathrm{ml}\right)$ were cultured in DMEM/F-12 supplemented with $10 \%$ calf fetal serum and $1 \%$ antibiotic-antimycotic solution (all from Sigma) in Falcon 24-well plates (Becton Dickinson, Lincoln Park, NJ, USA), $2 \mathrm{ml}$ medium per well, and in chamber slides (Nunc Inc., Naperville, TN, USA), $200 \mu$ medium per well, at $38{ }^{\circ} \mathrm{C}$ and $5 \%$ $\mathrm{CO}_{2}$ in humidified air. After $2 \mathrm{~d}$ pre-culture, the medium was replaced with medium of the same composition. In addition, cells transfected either with gene construct encoding EGFP + construct without p53 (control) and with that encoding EGFP + p53 were treated with $0,1,10$, or $100 \mathrm{ng} / \mathrm{ml}$ of human recombinant ghrelin (Peptides International Inc., Louisville, KY, USA) and porcine FSH (NHPP). All hormones were of biological grade. They were dissolved in culture medium immediately before experiment. After $2 \mathrm{~d}$ of culture, the medium from 24-well plates was aspirated and frozen at $-18{ }^{\circ} \mathrm{C}$ to await RIA. Luteinizing cells in chamber slides were washed in $700 \mu \mathrm{l}$ well ice-cold PBS (5 min), fixed in paraformaldehyde (4\% in PBS, $\mathrm{pH} 7.2-7.4$ ), and held at $4{ }^{\circ} \mathrm{C}$ to await immunocytochemistry.

Table 1 Characteristics of immunoassays used in experiments.

Coefficient of variation

\begin{tabular}{|c|c|c|c|c|}
\hline \multirow[b]{2}{*}{ Substance assayed } & \multirow[b]{2}{*}{ Specificity of assay (cross-reactivity of antiserum) } & \multirow[b]{2}{*}{$\begin{array}{l}\text { Sensitivity of assay } \\
(\mathrm{ng} / \mathrm{ml})\end{array}$} & \multicolumn{2}{|c|}{ Coefficient of variation } \\
\hline & & & Intra-assay & Inter-assay \\
\hline Progesterone & $\begin{array}{l}<0.001 \% \text { to cortisol, corticosterone, cortisol, } \\
\text { androstenediol, pregnenolone, estradiol, testosterone }\end{array}$ & 0.12 & 13.1 & 8.0 \\
\hline PGF & $\begin{array}{l}<0.01 \% \text { to PGA- } 1, \text { PGA- } 2, \text { PGB- } 1, \text { PGB- } 2,<0.1 \% \text { to } \\
\text { PGE- } 1 \text {, PGE- } 2,66 \% \text { to PGF- } 1,100 \% \text { to PGF- } 2\end{array}$ & 0.003 & 10.5 & 5.6 \\
\hline PGE & $\begin{array}{l}<28.0 \% \text { to PGA- } 1,<7.0 \% \text { to PGA- } 2,<0.6 \% \text { to } \\
\text { PGB- } 1,<1.4 \% \text { to PGB- } 2,<5.0 \% \text { to PGF- } 1 \\
<1.5 \% \text { to PGF- } 2,165 \% \text { to PGE- } 1,100 \% \text { to PGE- } 2\end{array}$ & 0.015 & 7.5 & 4.0 \\
\hline Oxytocin & $\begin{array}{l}<0.01 \% \text { to arginine-vasopressin, lysine-vasopressin, } \\
\text { arginine-vasotocin, ghrelin, leptin and FSH }\end{array}$ & 0.12 & 13.1 & 8.0 \\
\hline
\end{tabular}


At this time, after finishing the culture, cell numbers and viability were determined by trypan blue staining and counting in a hemocytometer. Viability was $70-80 \%$. No statistically significant differences in these indices between control and experimental groups were observed.

\section{Immunoassays}

Concentrations of $\mathrm{P}_{4}, \mathrm{OT}, \mathrm{PGF}$, and PGE were determined by RIA in 25-100 $\mu$ samples of incubation medium. $P_{4}$ was assayed using RIA/IRMA kits from DSL (Webster, MA, USA) according to the manufacturer's instructions. OT, PGE-2, and PGF metabolites (PGFM) were assayed by our own RIA/EIA systems (Kotwica \& Skarzynski 1993, Skarzynski et al. 1999, Duras et al. 2005) respectively. Determination of PGFM in medium reliably reflects PGF-2a secretion $(r=0.92 ; P<0.001)$ from cultured cells (Skarzynski et al. 1999). The characteristics of these assays are presented in Table 1.

\section{Immunocytochemical analysis}

The presence of p53, MAP3K5, and cyclin B1 was demonstrated by immunocytochemistry (Osborn \& Isenberg 1994) using primary mouse monoclonal antibodies against these substances (Chemicon, San Diego, CA, USA; dilution 1:500) cross-reacted with corresponding antigens of human, rat, mouse, and yeast origin. Secondary porcine polyclonal antibodies against mouse IgGs, labeled with horseradish peroxidase (Sevac, Prague, Czech Republic; dilution 1:1000) and $3,3^{\prime}$ diaminobenzidine (DAB) reagent (Boehringer Mannheim $\mathrm{GmbH}$ ) were used for the visualization of primary antibody. The presence of immunoreactivity in the cells was determined by one observer by using light microscopy. The percentage of cells containing visible antigen was counted. Cells processed without the primary antibody were used as negative control. The presence of cells containing EGFP was detected using a fluorescence microscope.

\section{Statistical analysis}

Each series of experiments was performed thrice. The data shown are the means of values obtained in these three separate experiments performed on separate days with separate groups of granulosa cells, each obtained from 15-20 animals.

\section{RIA}

Each experimental group was represented by four culture wells, i.e., each value represents means of 4 wells $\times 3$ experiments $=$ 12 replicates. Assays of hormone concentration in the incubation medium were performed in duplicates. The values of blank controls (serum-supplemented medium incubated without cells) were subtracted from the specific values determined by RIA in cell-conditioned medium to exclude any non-specific background (less than $10 \%$ of total values). Rates of secretion were calculated per $10^{6}$ viable cells/day.

\section{Immunocytochemistry}

In each chamber (three per group), 1000 cells were scored, i.e., each value representing the means of nine replicates $(9000$ cells in total). The percentage of cells containing antigen in different groups of cells was calculated.

Significant differences between the experiments were evaluated using two-way ANOVA. When the effects of treatments were revealed, data from the experimental and control groups were compared by Student's t-test using Sigma Plot 9.0 software (Systat Software, GmbH, Erkhart, Germany). Differences from control at $P<0.05$ were considered as significant.

\section{Declaration of interest}

There is no conflict of interest that could be perceived as prejudicing the impartiality of the research reported.

\section{Funding}

This research did not receive any specific grant from any funding agency in the public, commercial or not-for-profit sector.

\section{Acknowledgements}

The authors express their deep gratitude to Ms K Tóthová and Ing Ž Kuklová for skilful help in analyzing the samples, Dr N Perkins (University of Dundee, Dundee, UK) for kind provision of the gene constructs, Ministry of Agriculture of Slovak Republic for support of the present studies (project RUVVR 07-13), and Dr M Luck (University of Nottingham, Sutton Bonington, UK) for his kind help in editing this manuscript. OT, PGE-2, and PGFM antisera were kindly donated by Professors G Kotwica (University of Warmia and Mazury, Olsztyn, Poland), W W Thatcher (University of Florida, Gainesville, FL) and W J Silvia (University of Kentucky, USA).

\section{References}

Amsterdam A, Sasson R, Keren-Tal I, Aharoni D, Dantes A, Rimon E, Land A, Cohen T, Dor Y \& Hirsh L 2003 Alternative pathways of ovarian apoptosis: death for life. Biochemical Pharmacology 66 1355-1362.

Baker SJ, Preisinger AC, Jessup JM, Paraskeva C, Markowitz S, Willson JK, Hamilton S \& Vogelstein B 1990 p53 gene mutations occur in combination with $17 p$ allelic deletions as late events in colorectal tumorigenesis. Cancer Research 50 7717-7722.

Braithwaite AW, Del Sal G \& Lu X 2006 Some p53-binding proteins that can function as arbiters of life and death. Cell Death and Differentiation 13 984-993.

Brown L, Boswell S, Raj L \& Lee SW 2007 Transcriptional targets of p53 that regulate cellular proliferation. Critical Reviews in Eukaryotic Gene Expression 17 73-85.

Chaffin CL, Brogan RS, Stouffer RL \& VandeVoort CA 2003 Dynamics of Myc/Max/Mad expression during luteinization of primate granulosa cells in vitro: association with periovulatory proliferation. Endocrinology 144 1249-1256.

Cherian-Shaw M, Das R, Vandevoort CA \& Chaffin CL 2004 Regulation of steroidogenesis by p53 in macaque granulosa cells and H295R human adrenocortical cells. Endocrinology 145 5734-5744.

Chernigovskaya EV, Taranukhin AG, Glazova MV, Yamova LA \& Fedorov LM 2005 Apoptotic signaling proteins: possible participation in the regulation of vasopressin and catecholamines biosynthesis in the hypothalamus. Histochemistry and Cell Biology 124 523-533. 
Chowdhury I, Tharakan B \& Bhat GK 2006 Current concepts in apoptosis: the physiological suicide program revisited. Cellular and Molecular Biology Letters 11 506-525.

Dineva J, Wojtowicz AK, Augustowska K, Vangelov I, Gregoraszczuk EL \& Ivanova MD 2007 Expression of atrial natriuretic peptide, progesterone, apoptosis-related proteins and caspase- 3 in in vitro luteinized and leptintreated porcine granulosa cells. Endocrine Regulations 41 11-18.

Duras M, Mlynarczuk J \& Kotwica J 2005 Non-genomic effect of steroids on oxytocin-stimulated intracellular mobilization of calcium and on prostaglandin F2 and E2 secretion from bovine endometrial cells. Prostaglandins \& Other Lipid Mediators 76 105-116.

Findlay JK 1994 Peripheral and local regulators of folliculogenesis. Reproduction, Fertility, and Development 6 127-139.

Grimberg A, Coleman CM, Shi Z, Burns TF, MacLachlan TK, Wang W \& El-Deiry WS 2006 Insulin-like growth factor factor binding protein-2 is a novel mediator of p53 inhibition of insulin-like growth factor signaling. Cancer Biology \& Therapy 5 1408-1414.

Hassan I, Wunderlich A, Slater E, Hoffmann S, Celik I \& Zielke A 2006 Antisense p53 decreases production of VEGF in follicular thyroid cancer cells. Endocrine 29 409-412.

Herr D, Keck C, Tempfer C \& Pietrowski D 2004 Chorionic gonadotropin regulates the transcript level of VHL, p53, and HIF-2 $\alpha$ in human granulosa lutein cells. Molecular Reproduction and Development 69 397-401.

Hussein MR, Bedaiwy MA \& Falcone T 2006 Analysis of apoptotic cell death, BCl-2, and p53 protein expression in freshly fixed and cryopreserved ovarian tissue after exposure to warm ischemia. Fertility and Sterility 85 (Supplement 1) 1082-1092.

Jiang JY, Cheung CK, Wang Y \& Tsang BK 2003 Regulation of cell death and cell survival gene expression during ovaria follicular development and atresia. Frontiers in Bioscience 8 222-237.

Kotwica J \& Skarzynski D 1993 Influence of oxytocin removal from corpus luteum on secretory function and duration of estrous cycle in cattle. Journal of Reproduction and Fertility 97 411-417.

Maillet G, Feral C \& Benhaim A 2005 Apoptosis of the follicular cells: its implication in ovarian induction protocols. Gynécologie, Obstétrique \& Fertilité 33 653-658.

Marchetti A, Cecchinelli B, D'Angelo M, D'Orazi G, Crescenzi M, Sacchi A \& Soddu S 2004 p53 can inhibit cell proliferation through caspasemediated cleavage of ERK2/MAPK. Cell Death and Differentiation 11 596-607.

Mészárosová M, Sirotkin AV, Grossmann R, Darlak K \& Valenzuela F 2007 The effect of obestatin on porcine ovarian granulosa cells. Animal Reproduction Science 108 196-207.
Osborn M \& Isenberg S 1994 Immunocytochemistry of frozen and paraffin tissue sections. In Cell Biology. A Laboratory Handbook, vol 2, pp 361-367. Ed JE Celis. New York: Academic Press.

Schams D, Berisha B, Kosmann M, Einspanier R \& Amselgruber WM 1999 Possible role of growth hormone, IGFs, and IGF-binding proteins in the regulation of ovarian function in large farm animals. Domestic Animal Endocrinology 17 279-285.

Sirotkin AV \& Grossmann R 2007a Effects of ghrelin and its analogues on chicken ovarian granulosa cells. Domestic Animal Endocrinology 34 125-134.

Sirotkin AV \& Grossmann R 2007 b Leptin directly controls proliferation, apoptosis and secretory activity of cultured chicken ovarian cells. Comparative Biochemistry and Physiology. Part A, Molecular \& Integrative Physiology 148 422-429.

Sirotkin AV, Makarevich AV, Kotwica J, Marnet PG, Kwon HB \& Hetenyi L 1998 Isolated porcine ovarian follicles as a model for the study of hormone and growth factor action on ovarian secretory activity. Journal of Endocrinology 159 313-321.

Sirotkin AV, Makarevich AV, Kwon HB, Kotwica J, Bulla J \& Hetényi L 2001 Do GH, IGF-I and oxytocin interact by regulating the secretory activity of porcine ovarian cells? Journal of Endocrinology 171 475-480.

Sirotkin AV, Grossmann R, Maria-Peon MT, Roa J, Tena Sempere M \& Klein S 2006 Novel expression and functional role of ghrelin in chicken ovary. Molecular and Cellular Endocrinology 26 257-258 (15-25).

Sirotkin AV, Chrenek P, Darlak K, Valenzuela F \& Kuklová Z 2007 Some endocrine traits of transgenic rabbits. II. Changes in hormone secretion and response of isolated ovarian tissue to FSH and ghrelin. Physiological Research [in press].

Sirotkin AV, Chrenková M, Nitrayová S, Patraš P, Darlak K, Valenzuela F, Pinilla L \& Tena-Sempere M 2008 Effects of chronic food restriction and treatments with leptin or ghrelin on different reproductive parameters of male rats. Peptides 29 1362-1368.

Skarzynski D, Bogacki M \& Kotwica J 1999 Involvement of ovarian steroids in basal and oxytocin-stimulated prostaglandin (PG)F2 secretion from bovine endometrium in vitro. Theriogenology 52 385-397.

Tena-Sempere M 2008 Ghrelin and reproduction: ghrelin as novel regulator of the gonadotropic axis. Vitamins and Hormones 77 285-300.

Wathes DC 1989 Oxytocin and vasopressin in the gonads. Oxford Reviews of Reproductive Biology 11 226-283.

Received 23 May 2008

First decision 23 June 2008

Accepted 13 August 2008 